\title{
ECONOMIC FEASIBILITY STUDY OF FOOD-GRADE DYE PRODUCTION FROM RED MELINJO PEELS
}

\author{
Yuli Amalia Husnil ${ }^{1, *}$, Ermiziar Tarmizi ${ }^{1, *}$, Absharina Zatadini Edyatika \\ Putri $^{1}$, Mega Angelia Nusandari ${ }^{1}$, Latifa Hanum Lalasari ${ }^{2}$ \\ and Raskita Saragih ${ }^{3}$ \\ ${ }^{1}$ Department of Chemical Engineering, Institut Teknologi Indonesia, J1 Raya Puspiptek Serpong. \\ 15314. Tangerang Selatan, Indonesia \\ ${ }^{2}$ Research Center for Metallurgy and Materials, LIPI, Kawasan Puspiptek GD. 470. 15314. \\ Tangerang Selatan, Indonesia \\ ${ }^{3}$ Department of Food Technology, Institut Teknologi Indonesia, Jl. Raya Puspiptek Serpong. \\ 15314. Tangerang Selatan, Indonesia \\ *E-mail : yuli.husnil@gmail.com, ermitarmizi@gmail.com
}

\begin{abstract}
This study aims to analyze the economic feasibility of a dye factory of food-grade anthocyanin from red Melinjo on a scale of 300 tons/year. This dye factory was built using the conditions and operating parameters obtained from previous research where to produce 300 tons of anthocyanin dye per year required 160 thousand tons of Melinjo seeds. From the calculation of economic parameters using the steady estimate method, the return of investment (ROI) value is $53.8 \% \%$ which is an indication that this anthocyanin dye factory is an investment area that should be taken into account.
\end{abstract}

Keywords: Anthocyanin, Investment, Factory, ROI, Steady Estimate

(C) RASĀYAN. All rights reserved

\section{INTRODUCTION}

The market growth of the food dye will greatly depend on the development of the food and beverage industry which is the main consumer. The food industry is one of the industries that will be intensified by the Industrial Revolution 4.01.

PT Roha Lautan Pewarna is currently the sole producer of anthocyanin coloring products with a production capacity of 826 tons/year ${ }^{2}$. However, because of the increasing demand for anthocyanins as a food dye, it is necessary to enhance the food coloring factory to meet the market needs. For the period 2014 to 2015 the demand for imported food dye experienced an increase of $1.015 \%$. In order to reduce imports and increase foreign exchange by increasing exports, it is potential to establish new food dye factories along with the increase in market demand for food and beverage products. The establishment of this food dye factories is also based on other things including utilization of emping industrial waste, increasing the selling value of Melinjo peels, increasing job vacancies which means reducing unemployment and reducing import dependence from other countries and also increasing the state revenue from the industrial sector and saving the country's foreign exchange.

\section{EXPERIMENTAL}

\section{MARKET ANALYSIS}

The Central Statistics Agency (BPS) recorded that there was significant growth in the food and beverage industry in Indonesia. In 2016 food products dominated Indonesian export commodities with a value of USD 26.3 billion $^{3}$. While in 2017 there was an increase in the value of food product exports by $20.72 \%$ to USD 31.72 billion $^{4}$. This increase in export value indicates that domestic food production is also

Rasayan J. Chem., 12(2), 641-649(2019)

http://dx.doi.org/10.31788/RJC.2019.1225091

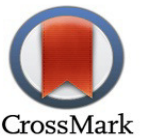


increasing. This will affect the necessity for food dye. The urgency for adding production capacity for food coloring agent is also due to the alarming situation of children food safety. It was found that 40-45\% of children snacks contained harmful chemical based food coloring substances such as Rhodamine B and methyl yellow 5 .

Indonesia's import value of food dye has fluctuated from the period of 2010 to 2017 as shown in Figure 1. Currently, Indonesia still imports food dye with the main sources coming from Denmark, Japan, Malaysia, and the United Kingdom ${ }^{6}$. From the graph shown in Figure 1, information can be extracted that the average percentage of Indonesia's import growth of food dye is $6.5 \%$. The import value of food dye from the year 2018 to 2020 can be projected using the percent growth rate. In 2020 it is projected that Indonesia's import value for food dye will reach the point of 167 tons. This projection is carried out by assuming that there is no additional production of natural food dye in Indonesia and the export value of domestic food and beverage products continues to grow with a stable value.

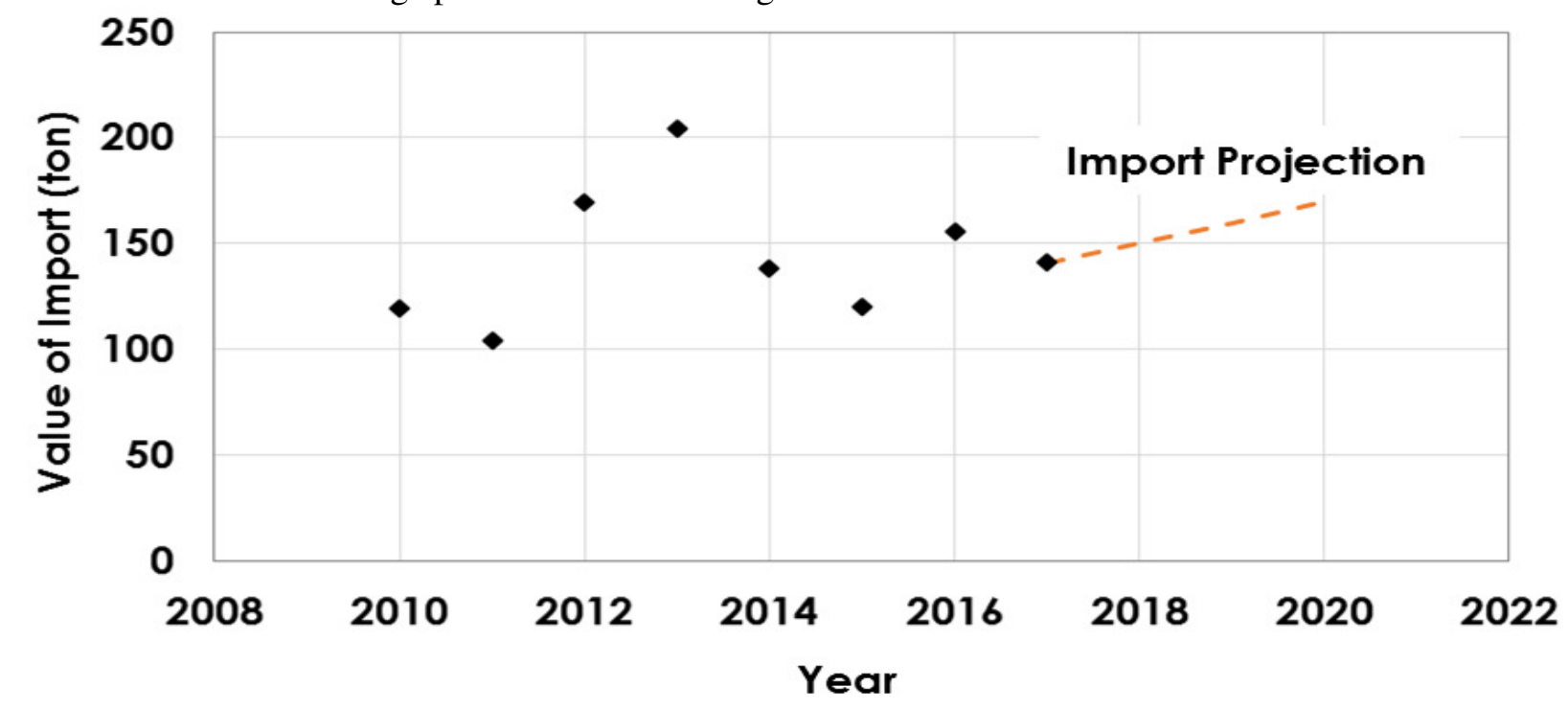

Fig.-1: Total Import of Food Dye and Import Projections From 2018-2020

Currently, there are factories in Indonesia that have produced food dye, namely PT Roha Lautan Pewarna with a capacity of 826 tons/year. Referring to the growth projection of the domestic food industry for the next few years, the production of natural food dyes should also grow proportionally. This is also to prevent dependence on imported food dye products.

Anthocyanin is a natural pigments contained in fruit and flowers. It usually has colors of purple, blue, red, and slightly blackish in color, and are soluble in water ${ }^{7}$. Anthocyanin can be used as an antioxidant, pigment or as a free radical scavenging agent ${ }^{8}$. Melinjo (Gnetum gnemon) is a native flora in Southeast Asia and used as part of culinary in Indonesia especially in Java region. Approximately in every 100 gr of Red Melinjo peels contain 0.6 gr of anthocyanin ${ }^{9}$. Utilization of red Melinjo peels as a raw material for food dye for industrial scale has never been done before. Patents related to the design of the production process as a reference for the establishment of Melinjo peels-based food dye factories are also not yet available. Therefore, this study was conducted as a first step to analyze the economic feasibility of Melinjo peels-based food dye production at a relatively small capacity in order to increase the selling value of domestic natural ingredients.

\section{Feasibility Analysis of Raw Materials \\ Design Process}

The natural food dye factory from the red Melinjo peels that will be established as the main product which is a thick dye solution with $95 \%$ of product purity. The design of the production process in this study refers to two patents on the production of natural anthocyanin dyes using grapes as the raw material ${ }^{10,11}$. Figure 2 presents the process flow diagram of food grade dye production from Red Melinjo 
peels. The dimensions and operating conditions of each unit are presented in Table-1. The production process of making natural anthocyanin dyes from Melinjo peels is divided into 4 stages, namely: (1) Preparation of raw materials, (2) Extraction, (3) Separation, and (4) Purification.

\section{Preparation of Raw Materials}

The main raw materials required to produce natural dyes are Red Melinjo fruit, bioethanol, and citric acid. Melinjo red peel is stored in a storage tank at a temperature of $30^{\circ} \mathrm{C}$ and $1.1 \mathrm{~atm}$. While bioethanol is stored in a storage tank at $30^{\circ} \mathrm{C}$ and 1.29 atm. Citric acid is available in a solid form so it needs to be dissolved with water in the dissolution tank which is equipped with stirring at a speed of $188 \mathrm{rpm}$. Before dissolving, citric acid is stored in a storage tank at $30^{\circ} \mathrm{C}$ and $1.1 \mathrm{~atm}$.

The Red Melinjo fruit is inserted to the skin and seed separator using a screw conveyor. The efficiency of this separator is assumed to be $100 \%$, meaning that all the seeds and peels of the Melinjo are completely separated. Seeds that have been separated from their peels then flow to the seed holder tank while the Melinjo peel flows towards the Cabinet Dryer.

The Cabinet Dryer's function in this process is to reduce the water content of the Melinjo peel from $72 \%$ to $4.7 \%$ wet weight. The air used for this drying process is heated to a temperature of $50^{\circ} \mathrm{C}$ using a $100^{\circ} \mathrm{C}$ saturated steam. The temperature of wet air and dry Melinjo peels after the drying process are $35^{\circ} \mathrm{C}$ and $40^{\circ} \mathrm{C}$ respectively. Dried Melinjo peel is then reduced to the size of 35 mesh in an abrasive screen.

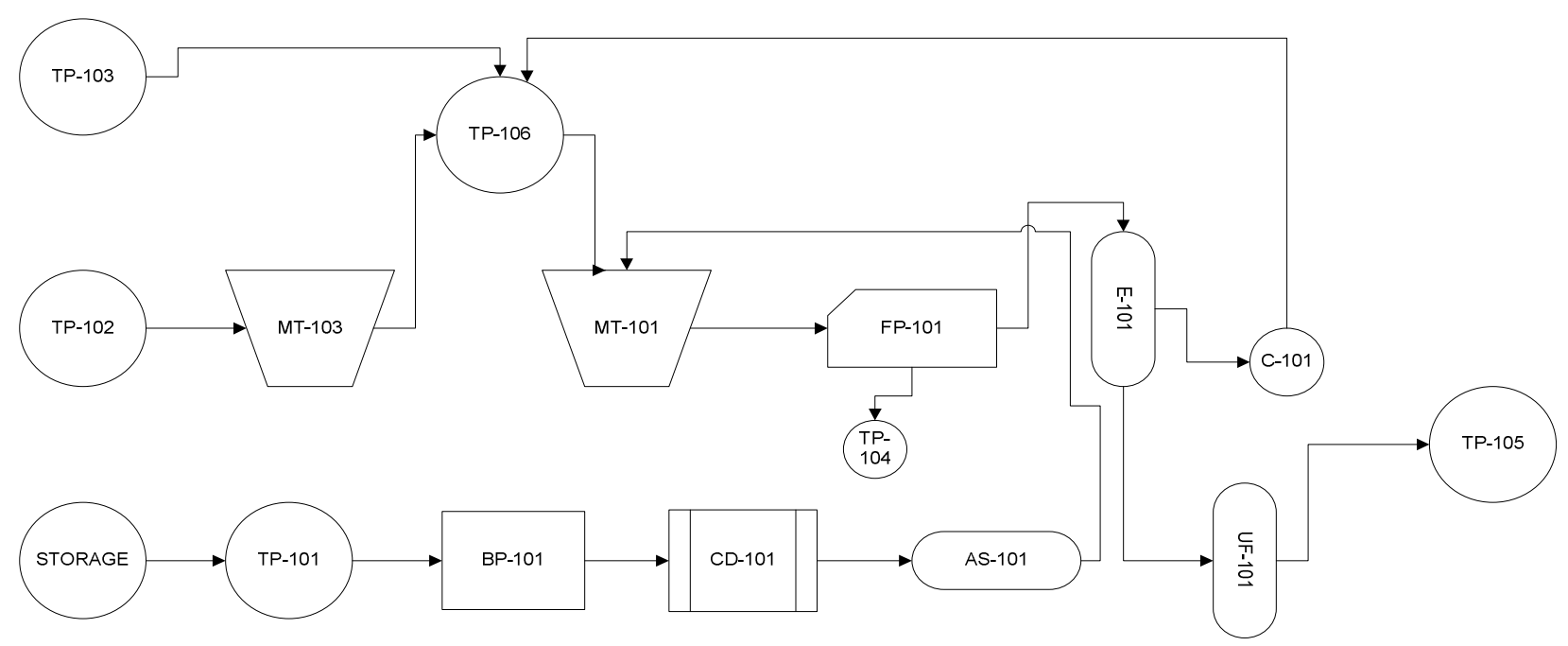

Fig.-2: Process Flow Diagram of Red Melinjo Peels-based Food Dye Production

\section{Extraction}

The Melinjo peels sized of 35 mesh was mixed with bioethanol and citric acid in the mixing tank. This mixture is then left to stand for 3 days to maximize the extraction process of the components of Melinjo peels into bioethanol. Comparison of bioethanol composition with Melinjo peels is 5: $1(\mathrm{~b} / \mathrm{b})$, while the citric acid mass required is $5 \%$ of bioethanol requirement. In the extraction process, as much as $25 \%$ of the constituent components of Melinjo peels dissolve into bioethanol. After the extraction process is complete, the dye solution which still contains Melinjo peels is flowed using a centrifugal pump towards the filter press.

\section{Separation}

The Filter press functions to separate the dye solution form the solids of Melinjo peels with a recovery of 95\%.Melinjo peels that have been separated from the dye solution then flows into the Melinjo peels disposal tank. The dye solution proceeded from the filter press will be concentrated in the falling film evaporator by evaporating bioethanol, citric acid, and water. In this evaporator, the dye solution will be dropped at a high speed into the tube to form a film layer inside the tube. The saturated steam at a temperature of $164.96^{\circ} \mathrm{C}$ is blown into the shell. The operating conditions of the evaporator are maintained at a temperature of $50^{\circ} \mathrm{C}$ and a vacuum pressure. The evaporation process is designed to 
produce dye products with a purity of $98.5 \%$. This product is then distributed to the ultrafiltration unit for the refining process. Bioethanol, citric acid, and water in the steam product flow from the evaporator are then condensed to be reused in the extraction process.

\section{Purification}

Ultrafiltration functions to separate macromolecules such as proteins, fats, and carbohydrates from dye products to obtain a higher product's purity. This separation is also a necessity to be done to reduce the risk of breeding of the microorganisms in the dye solution. The process of separating macromolecules using a membrane sized of $1-10 \AA$ and having an efficiency of $82 \%$. Whereas for components other than macromolecules, it is assumed that the mass that is left behind or held in the membrane is 5\%. The macromolecules which pass the ultrafiltration process are $18 \%$ and other components then flow to the product tank through a centrifugal pump.

\section{Dimensions of Unit Operations}

Designing the dimensions of the unit operation begins by determining the duration of operation of each unit. By using the data of feed flow rate that must be processed on these units and the specified duration then the capacity of the unit is obtained. The dimensions for the processing units are then designed according to the principles described in some literature. ${ }^{12,13,14}$

The production of food dye from Melinjo peels is carried out in batches. For each batch, the process can be completed within 4 days. Some main units such as extraction tanks that operate with relatively long durations must be provided in more than one unit to optimize the production process. With the existence of several units that can be operated in parallel, within 14 days 6 batches can be completed. The process duration and the specifications of the units are shown in Table-1.

Table-1: Process Duration and Unit Specifications

\begin{tabular}{|c|c|c|c|c|c|}
\hline No & Name & Code & $\begin{array}{l}\text { Duration } \\
\text { (hour) }\end{array}$ & Specifications & Total \\
\hline 1. & $\begin{array}{l}\text { Silo of Melinjo } \\
\text { Peels }\end{array}$ & TP-101 & 1 & Dimension (D x H): 5.8 × $20 \mathrm{~m}$ & 1 \\
\hline 2. & Conveyor & SC-101\&FC-101 & 1.1 & length: 20 inch & 2 \\
\hline 3. & Washing Tub & BP-101 & 1 & $\begin{array}{l}\text { Dimension ( } \mathrm{L} \times \mathrm{W} \times \mathrm{H}): 9.3 \times 4.7 \text { x } 6 \\
\mathrm{~m}\end{array}$ & \\
\hline 4. & Conveyor & SC-102\&FC-102 & 1.0 & length: 20 in & 2 \\
\hline 5. & Cabinet Dryer & CD-101 & 8 & $\begin{array}{l}\text { - Capacity } 8 \text { ton/hour } \\
\text { - Dimension (L x W x H): } 1.4 \text { x } 1.2 \text { x } \\
2 \mathrm{~m}\end{array}$ & 8 \\
\hline 6. & Conveyor & SC-103\&FC-103 & 1.0 & length: 12 inch & 2 \\
\hline 7. & Abrasive Screen & AS-101 & 2.3 & $\begin{array}{l}\text { - Capacity } 23 \text { ton/hour } \\
\text { - Dimension (L x W x H): } 2.5 \text { x } 1.5 \text { x } \\
1.2 \mathrm{~m}\end{array}$ & 1 \\
\hline 8. & Conveyor & SC-104\&FC-104 & 1.0 & length: 12 inch & 2 \\
\hline 9. & Extraction Tank & MT-101/MT-102 & 72 & Dimension $(\mathrm{D} \times \mathrm{H}): 6.1 \times 6.1 \mathrm{~m}$ & 4 \\
\hline 10. & Centrifugal Pump & P-105/P-106 & 2 & BHP: $5.4 \mathrm{hp}$ & 2 \\
\hline 11. & Filter Press & FP-101 & 1 & $\begin{array}{l}\text { Dimension }(\mathrm{L} \times \mathrm{W} \times \mathrm{H}): 2.5 \times 1.5 \times 1.2 \\
\mathrm{~m}\end{array}$ & 1 \\
\hline 12. & Centrifugal Pump & P-107 & 2.5 & BHP: $18.7 \mathrm{hp}$ & 1 \\
\hline 13. & Evaporator & E-101 & 3 & $\begin{array}{l}\text { - A: } 5175.8 \mathrm{ft}^{2} \\
\text { - } \mathrm{Nt}: 3984 \text { tube } \\
\text { - } \mathrm{L}: 20 \mathrm{ft}\end{array}$ & 4 \\
\hline 14. & Centrifugal Pump & P-108 & 0.2 & BHP: $1.4 \mathrm{hp}$ & 1 \\
\hline 15. & Ultrafiltration & UF-101 & 0.2 & Area of membrane: $2.3 \mathrm{~m}^{2}$ & 1 \\
\hline 16. & Centrifugal Pump & P-109 & 0.2 & BHP: $0.3 \mathrm{hp}$ & 1 \\
\hline 17. & Centrifugal Pump & P-110 & 0.2 & BHP: $0.1 \mathrm{hp}$ & 1 \\
\hline 18. & Mixing Tank & MT-103 & 1 & Dimension $(\mathrm{D} \times \mathrm{H}): 2.1 \times 5.5 \mathrm{~m}$ & 1 \\
\hline
\end{tabular}

Description: units not listed on tables are operated in parallel with other devices. 


\section{Economic Analysis}

\section{RESULTS AND DISCUSSION}

Economic performance is one of the main factors to assess the feasibility of a production process. The economic feasibility of the production of anthocyanin dyes from red Melinjo peels can be determined after identifying several factors such as production capacity, costs of raw material, chemicals, utilities and investment in equipment.

The economic evaluation in this study is based on several assumptions:

1. The production process lasted for 332 days/year. To do thorough maintenance, shut down has been done for 33 days in one year.

2. The process used is a batch process.

3. The physical construction of the factory will be carried out at the beginning of 2019 with a oneyear construction, investment, and installation period so that the factory is expected to start commercially operating in 2020 .

4. Working Capital is calculated for 3 months.

5. The working period of each unit is 10 years.

6. The assumption of the value of the dollar towards the rupiah is 1 US\$ is Rp. 13.400,-

7. In 2017 market conditions are stable with the bank's interest rate is $10 \%$ per year.

8. The increase in the price of raw materials and production result is $10 \%$ per year.

9. The increase in the employee's salary is $10 \%$ per year.

10. Salvage Value is 10\% from Fixed Direct Capital Investment (FDCI) without land prices.

The approach in calculating economic analysis used is the steady estimate approach where analysis is based solely on process flow diagrams and rough calculations of the main unit dimensions ${ }^{12}$. More detailed diagrams such as plot plans, piping diagrams, and instrumentation are not needed in this method. In this method, costs, other than investment for units, are obtained by comparing them with the price of the main unit. The prices of production equipment and supporting equipment are calculated using the data from reference handbooks and some related online sites. ${ }^{13,14,16-18}$

The steady estimate method has an accuracy range of $+30 \%$ to $-20 \%$ so that the results of this study may not accurately reflect the actual conditions of the economic feasibility of the production of anthocyanin dyes ${ }^{15}$. However, the results of this study can be used as a reference to analyze which parts of the production process that need to be optimized.

\section{Total Capital Investment (TCI)}

TCI is the result of an addition of fixed and working capital investment. Fixed capital investment (FCI) is the investment required to build a factory that is ready to operate. The FCI consists of equipment costs, installation, piping, instrumentation, electricity, buildings, utilities, storage, area development, additional buildings, contractor fees, and unexpected costs. Whereas working capital investment (WCI) is an investment required to operate the factory for 3 months, wherein this period all operating variables are adjusted until the factory is ready to produce ${ }^{17}$.The TCI calculation results are shown in Table 2 down below.

Table-2: Summary of the Results of TCI Calculations

\begin{tabular}{c|c|c}
\hline Type & & Cost \\
\hline MAIN EQUIPMENT & & \\
\hline Storage Tanks & TP-101 s/d TP-106 & $6,885,516,779$ \\
\hline Mixing Tanks & MT-101 s/d MT-103 & $1,728,845,365$ \\
\hline Cabinet Dryer & CD-101 & $6,215,067,766$ \\
\hline Abrasive screen & AS-101 & $154,499,139$ \\
\hline Filter Press & FP-101 & $16,994,905$ \\
\hline Ultrafiltration & UF-101 & 432,598 \\
\hline Falling Film Evaporator & E-101 & $9,066,009,479$ \\
\hline
\end{tabular}


RASĀYAN J. Chem.

Vol. 12 | No. 2 |641 - 649| April - June | 2019

\begin{tabular}{|c|c|c|}
\hline Pumps & $\mathrm{P}-101 \mathrm{~s} / \mathrm{d} \mathrm{P}-111$ & $1,138,658,657$ \\
\hline Screw Conveyor & SC-101 s/d SC-105 & $2,098,098,306$ \\
\hline Flight Conveyor & FC-101 s/d 105 & $386,247,847$ \\
\hline Condenser & $\mathrm{C}-101$ & $253,672,136$ \\
\hline Washing Tub & BP-101 & $483,767,704$ \\
\hline Main Equipment Costs (MEC) & & $28,427,810,681$ \\
\hline Transportation and insurance costs (10\% MEC) & & $2,842,781,068$ \\
\hline Port administration fee (5\% MEC) & & $142,139,053$ \\
\hline SUBTOTAL & & $31,412,730,803$ \\
\hline Import Duty (10\% subtotal) & & $3,141,273,080$ \\
\hline TOTAL MAIN EQUIPMENTS & & $34,554,003,883$ \\
\hline \multicolumn{3}{|l|}{ SUPPORTING EQUIPMENT } \\
\hline Water Tanks and Fuel Tanks & TU-101 s/d TU-196 & $11,264,037,828$ \\
\hline Water Tubs & BU-101 dan BU-102 & $1,588,251,149$ \\
\hline Utility pump & PU-101 s/d PU-109 & $1,307,193,908$ \\
\hline Generator & G-101 & $3,229,032,006$ \\
\hline Boiler & B-101 & $8,485,092,716$ \\
\hline Air Heater & AH-101 & $865,195,179$ \\
\hline Cooling Tower & CT-101 & $1,507,911,597$ \\
\hline Operational Vehicles & & $1,000,000,000$ \\
\hline Supporting Equipment Costs (SEC) & & $29,246,714,383$ \\
\hline Transportation and insurance costs ( $10 \%$ SEC) & & $2,924,671,438$ \\
\hline Port administration fee (5\% SEC) & & $146,233,572$ \\
\hline SUBTOTAL & & $32,317,619,393$ \\
\hline Import Duty (10\% subtotal) & & $3,231,761,939$ \\
\hline TOTAL SUPPORTING EQUIPMENTS & & $35,549,381,333$ \\
\hline TOTAL equipment & & $70,103,385,215$ \\
\hline $\begin{array}{c}\text { Physical plant cost }(\mathrm{PPC})=3.4 * \text { TOTAL } \\
\text { EQUIPMENTS }\end{array}$ & & $238,351,509,732$ \\
\hline $\begin{array}{c}\text { Auxiliary plant cost }(\mathrm{APC})=0.45 * \text { TOTAL } \\
\text { EQUIPMENTS }\end{array}$ & & $31,546,523,347$ \\
\hline $\mathrm{FCI}=\mathrm{PPC}+\mathrm{APC}$ & & $269,898,033,079$ \\
\hline $\mathrm{WCI}=0.25 * \mathrm{FCI}$ & & $67,474,508,270$ \\
\hline $\mathrm{TCI}=\mathrm{FCI}+\mathrm{WCI}$ & & $337,372,541,349$ \\
\hline
\end{tabular}

\section{Total Production Cost (TPC)}

Production costs are one of the determinant factors of the selling price of a product. From these calculations, profit which will be obtained from the sale can be estimated. Total Product Cost (TPC) consists of two parts, namely manufacturing costs or costs required to make a product and general expense, or costs used to support the operation of factory activities.

Manufacturing costs consist of direct costs, overhead factory, and fixed costs. Direct Cost is a cost that is directly used for plant operations, including raw material costs, supporting facilities costs, employee's salaries, maintenance and repairs, royalty and patent fees and laboratory fees. Whereas plant overhead costs are composed of hospital services and treatment costs, factory general maintenance, security, 
salvage and distribution costs. Fixed Cost is a cost that is constant from year to year or does not change with the changes in production capacity, including depreciation, taxes and insurance costs. Last, general expenses namely costs used to support the operation of factory activities, including administrative costs, distribution, and sales costs, research and development cost and bank interest payments. TPC for the production of anthocyanin dyes from Melinjo peels in the first year, when new production capacity was $80 \%$, is shown in Table- 3 .

Table-3: Summary of the Results of TPC Calculations

\begin{tabular}{|c|c|c|c|c|c|}
\hline \multicolumn{4}{|c|}{ TOTAL PRODUCTION COST (TPC) } & Fixed Cost(Rp) & Variable $\operatorname{Cost}(\mathrm{Rp})$ \\
\hline \multicolumn{4}{|c|}{ Manufacturing Cost } & & \\
\hline 1. & \multicolumn{3}{|c|}{ DirectManufacturingCost (DMC) } & & \\
\hline a. & Raw Material Costs & & & & $197,835,014,904$ \\
\hline b. & Employee salary & & & $5,220,145,000$ & \\
\hline c. & $\begin{array}{c}\text { Maintenance and Repair Costs (increase by } \\
5 \% \text { per year) }\end{array}$ & $2 \%$ & DFCI & $3,791,816,486$ & \\
\hline d. & Royalty and Patent Fees & $0.5 \%$ & TS & & $4,663,200,000$ \\
\hline e. & Laboratory Costs & $0.5 \%$ & BB & & $989,175,075$ \\
\hline f. & Product packaging costs & $5.0 \%$ & BB & & $9,891,750,745$ \\
\hline g. & The cost of supporting facilities & & & $106,278,356$ & $492,474,863,819$ \\
\hline h. & Start-Up Cost & & & $4,453,947,104$ & \\
\hline \multicolumn{4}{|c|}{ Total Direct Manufacturing Costs (DMC) } & $13,572,186,945$ & $705,854,004,543$ \\
\hline & Plant Overhead Cost & $20 \%$ & $(b+c)$ & $1,802,392,297$ & \\
\hline \multicolumn{4}{|c|}{ Fixed Manufacturing Costs (FMC) } & & \\
\hline 2. & \multicolumn{3}{|l|}{ Depreciation } & $41,483,719,541$ & \\
\hline 3. & \multicolumn{3}{|c|}{$\begin{array}{l}\text { Land and Building Tax is estimated to be } 0.1 \% \text { x (land + } \\
\text { building), increases by } 10 \% / \text { year }\end{array}$} & $31,136,037$ & \\
\hline a. & Insurance costs (increasesby 10\%) per year & $0.5 \%$ & DFCI & $947,954,122$ & \\
\hline b. & Total FixedManufacturingCost (FMC) & & & $42,462,809,700$ & \\
\hline B. & \multicolumn{3}{|l|}{ General Expenses } & & \\
\hline a. & Administrative costs & $5 \%$ & $\mathrm{~b}$ & $261,007,250$ & \\
\hline b. & Distribution and sales costs & $10 \%$ & $\mathrm{f}$ & & $989,175,075$ \\
\hline c. & Bank interest & & & & $9,500,000,000$ \\
\hline \multicolumn{4}{|c|}{ Total General Expenditures } & $261,007,250$ & $10,489,175,075$ \\
\hline \multirow{2}{*}{\multicolumn{4}{|c|}{ Total Production Cost (TPC) }} & $58,098,396,193$ & $716,343,179,618$ \\
\hline & & & & \multicolumn{2}{|c|}{$774,441,575,811$} \\
\hline
\end{tabular}

\section{Return on Investment (ROI) and Break Even Point}

The ROI value is calculated by first calculating net income (profit), which is the subtraction between the revenue from sales and TMC. The total sales of dyeing products produced up to the 10th year are shown in Table 4 where the price of the dyeing products is $\mathrm{Rp} .2,897,837 / \mathrm{L}$. It is assumed that the selling price increases by $10 \%$ per year.

Table-4: Total Sales of Dyeing Products Produced Until the 10th Year

\begin{tabular}{c|c|c}
\hline Year & Production Capacity & Production Sales (Total Sales) \\
\hline 1 & $80 \%$ & $932,640,000,000$ \\
\hline 2 & $90 \%$ & $1,154,901,200,000$ \\
\hline 3 & $100 \%$ & $1,410,618,000,000$ \\
\hline 4 & $100 \%$ & $1,551,679,800,000$ \\
\hline 5 & $100 \%$ & $1,706,847,780,000$ \\
\hline 6 & $100 \%$ & $1,877,532,558,000$ \\
\hline 7 & $100 \%$ & $2,065,285,813,800$ \\
\hline 8 & $100 \%$ & $2,271,814,395,180$ \\
\hline
\end{tabular}


RASĀYAN J. Chem.

Vol. 12 | No. 2 |641 - 649| April - June | 2019

\begin{tabular}{c|c|c}
9 & $100 \%$ & $2,498,995,834,698$ \\
\hline 10 & $100 \%$ & $2,748,895,418,167$ \\
\hline
\end{tabular}

Depreciation is a reduction in income tax which provides an opportunity for taxpayers to collect sources of funds to cover costs that must be paid. Depreciation can be calculated by subtracting the salvage value from the FCI then dividing it by the age of the plant ${ }^{15}$. If the salvage value is assumed to be zero and the factory has existed for 10 years, the depreciation value is equal to $10 \%$ of the FCI. By using equation (1) where the value of profit is determined from sales in the first year, therefore the ROI value of this project is $53.3 \%$. The value of ROI is calculated to measure the feasibility of a plant construction project by comparing it with the minimum acceptable rate of return (MARR). If it is assumed that the MARR value is $20 \%$ so that ROI> MARR, then this project is feasible to be followed up.

ROI $\%={ }^{\text {Profit }} /(\mathrm{FCl}+$ Depreciation $)$

The break-even point (BEP) is the point at which companies start earning profits from the products sold. At this point, the cost of production equals the revenue from sales. The general formula for calculating $\mathrm{BEP}$ can be seen in equation (2) down below.

$\mathbf{B E P}=\frac{\mathrm{FC}}{(\mathrm{TS}-\mathrm{VC})} \times 100 \%$

Where:

FC: Total Fixed Cost

TS: Total Sales

VC: Total Variable Cost

A summary of the results of calculating the BEP of the dye plant from Melinjo peels from the 1st year up to the 10th year can be seen in Table-5.

Table-5: BEP Values up to the 10th Year

\begin{tabular}{c|c|c|c|c}
\hline Year & $\begin{array}{c}\text { Total } \\
\text { Fixed Cost (Rp) }\end{array}$ & $\begin{array}{c}\text { Total } \\
\text { Variable Cost (Rp) }\end{array}$ & $\begin{array}{c}\text { Total } \\
\text { Sales (Rp) }\end{array}$ & $\begin{array}{c}\text { BEP } \\
(\%)\end{array}$ \\
\hline 1 & 58.098 .396 .193 & 717.826 .942 .229 & 932.640 .000 .000 & 27,05 \\
\hline 2 & 60.144 .772 .595 & 909.804 .591 .009 & 1.154 .142 .000 .000 & 24,62 \\
\hline 3 & 62.445 .652 .961 & 1.102 .219 .500 .122 & 1.410 .618 .000 .000 & 20,25 \\
\hline 4 & 64.291 .017 .643 & 1.206 .978 .950 .134 & 1.551 .679 .800 .000 & 18,65 \\
\hline 5 & 39.097 .832 .007 & 1.322 .451 .845 .147 & 1.706 .847 .780 .000 & 10,17 \\
\hline 6 & 41.303 .759 .190 & 1554.209 .529 .662 & 1.877 .532 .558 .000 & 12,77 \\
\hline 7 & 43.716 .452 .162 & 1.568 .555 .482 .628 & 2.065 .285 .813 .800 & 8,80 \\
\hline 8 & 46.355 .896 .155 & 1.725 .411 .030 .891 & 2.271 .814 .395 .180 & 8,48 \\
\hline 9 & 49.244 .040 .357 & 1.897 .952 .133 .980 & 2.498 .995 .834 .698 & 8,19 \\
\hline 10 & 52.404 .992 .579 & 2.087 .747 .347 .378 & 2.748 .895 .418 .168 & 7,93 \\
\hline
\end{tabular}

CONCLUSION

A study to analyze the economic feasibility of the production process of food dye from Red Melinjo peels has been carried out. Through the steady estimate approach, it is known that this production process is broadly economically feasible. With a production capacity of 300 tons per year, the ROI value is $53.3 \%$, which is greater than the assumed MARR value of $20 \%$. 


\section{ACKNOWLEDGMENT}

This research was carried out at organic chemistry laboratory at the Department of Chemical Engineering, Institut Teknologi Indonesia. The authors are grateful for the main financial supports from RISTEK_DIKTI budget 2018 No: 044/KM/PNT/2018, 6 March 2018.

\section{REFERENCES}

1. https://www.ekonomi.kompas.com/read/2018/04/04/134003826/5-industri-utama-disiapkan-untukrevolusi-industri-40.

2. Annual Report PT. Lautan Luas, Tbk, (2013).

3. Ringkasan Eksekutif Perkembangan Ekspor dan Impor Industri Pengolahan Bulan Desember, The Ministry of Industry Republic of Indonesia, (2016).

4. Ringkasan Eksekutif Perkembangan Ekspor dan Impor Industri Pengolahan Bulan Desember, The Ministry of Industry Republic of Indonesia, (2017).

5. O. Martony, J. Silalahi, Z. Lubis, H. Santosa and R. Siburian, Rasayan J. Chem., 10(4), 1505(2017), DOI: $10.7324 /$ RJC.2017.1041795

6. http://www.trademap.org

7. M. Zulfajri and Muttakin, Rasayan J. Chem., 11(1), 135(2017), DOI: 10.7324/RJC.2018.1111983

8. A.A.S.A. Sukmaningsih, S. Permana, D.J.D.H. Santjojo, A.Y.P. Wardoyo and S.B. Sumitro, Rasayan J. Chem., 11(3),1193(2018), DOI: 10.31788/RJC.2018.1133047

9. E. Tarmizi, Y. A. Husnil, L. H. Lalasari, R. Saragih, In Proceedings of Seminar Nasional Energi dan Industri Manufaktur SIGER 2017, Universitas Negeri Lampung, Indonesia, pp. II-1-II-6, (2017).

10. T. Phillip, US Patent, US 3963700A, (1974).

11. B. Hilton, R. Lin and M. Topor, US Patent, US4320009A, (1977).

12. M. Peters, K. Timmerhaus, Plant Design and Economics for Chemical Engineers, fourth ed., McGraw-Hill Inc, Singapore, (1991).

13. R. K. Sinnott, 1999, Chemical Engineering Design, Vol. 6, Butterworth Heinemann, London, UK, pp. 634-723.

14. D.Q. Kern, 1950, Process Heat Transfer, McGraw-Hill, New York, USA, pp. 127-171.

15. M. El-Galad, K. El-Khatib and F. Zaher, Egyptian Journal of Petroleum, 24, 455(2015), DOI: 10.1016/j.ejpe.2015.06.002

16. https://www.matche.com/equipcost/Default.html

17. http://www.mhhe.com/engcs/chemical/peters/data/ce.html

18. https://www.alibaba.com/catalog/Food\&Beverage Machinery_cid100006936?spm=a272h.12365639.channel_left_category.7.10002f91tazoeC

[RJC-5091/2018] 